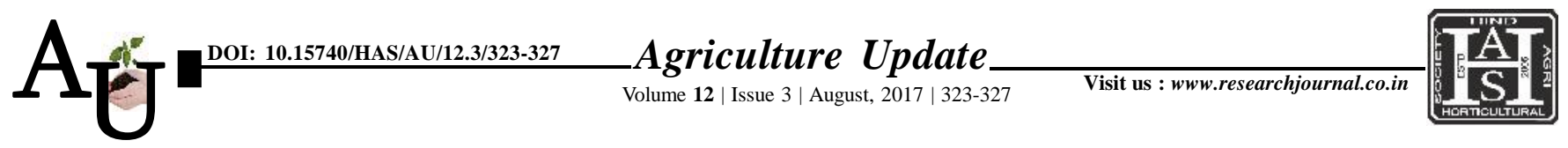

e ISSN-0976-6847

\title{
Research article: Training needs of potato growers in Sepahijala district of Tripura
}

\author{
RAJIB DAS AND K.K. JHA
}

Article Chronicle : Received :

10.04.2017;

Revised :

01.06.2017;

Accepted :

15.06.2017

\section{KeY Words :}

Training needs, Potato growers, Correlates
SUMMARY : Potato (Solanum tuberosum L.) is the fourth most important food crop and the primary non-grain food commodity in the world. At present China is the biggest potato producer globally. Total potato produced from China and India accounts for one third production of the rest of world. India accounted for 45.57 million MT of potato from an area of 20.63 lakh ha in the year 2015-16 with an average productivity of $22.10 \mathrm{t} / \mathrm{h}$. The potato grows quickly and contains more energy and protein per unit area when compared to a cereal crop. Therefore, it plays a vital role in ensuring food security, which is a major concern for the country. In North Eastern region of India, the state of Assam leads in area and the state of Tripura leads in productivity of potato. Tripura having an area of 5.4 thousand hectare under potato cultivation has an average productivity of 17.80 tonnes/ha which is below the average national productivity of 22.10 tonnes/ha (NHRDF, 2016). A study was conducted in Sepahijala district of Tripura by randomly selecting two of its rural development blocks. The main objective of the study was to analyse the socio - economic and personal characteristics of the potato growers and assess their perceived training needs in context of improved potato cultivation and increase the productivity of the crop. Data analysis was done using SAS software. The findings revealed that majority of the farmers had training needs in the area of disease management followed by insect pest management and balanced use of manures and fertilizers. Correlation analysis revealed that variables age, education and knowledge had highly significant association with the variable "training needs" of the potato farmers. Variables age and knowledge were found important to explain training needs of the potato growers.

How to cite this article : Das, Rajib and Jha, K.K. (2017). Training needs of potato growers in Sepahijala district of Tripura. Agric. Update, 12(3): 323-327; DOI : 10.15740/HAS/AU/12.3/323-327.
Author for correspondence :

\section{K.K. JHA}

Department of Agricultural Extension, Nagaland University, SASRD, MEDZIPHEMA CAMPUS (NAGALAND) INDIA

Email:kkjhanurd@ rediffmail.com

See end of the article for authors' affiliations 